\title{
EVALUATION OF CURRENT APHID CONTROL MEASURES TO LIMIT VIRUS INFECTION IN POTATOES
}

\author{
R.F. VAN TOOR and D.A.J. TEULON \\ Crop \& Food Research, Private Bag 4704, Christchurch, New Zealand \\ Corresponding author: vantoorr@crop.cri.nz.
}

\begin{abstract}
The effect of current aphid control measures to limit virus infection in potatoes is being studied in a 3-year programme. A survey of 15 randomly selected potato growers of the 66 registered in Canterbury indicated that $94 \%$ of growers used either imidacloprid or phorate as a seed treatment to control aphids during 2001-02. Between 18 December 2001 and 18 March 2002, 40\% of growers used 1-5 foliar applications of either dimethoate, chlorpyrifos, pirimicarb, methamidophos or acephate at label rates to control aphids in potato foliage. Field trials at Pukekohe and Lincoln compared aphid numbers in untreated and imidacloprid treated seed potatoes with or without fortnightly foliar applications of methamidophos, or foliar applications of lambda-cyhalothrin when apterous aphids colonise foliage. In plots treated with repeated applications of methamidophos aphid numbers were higher, due to the higher mortality of aphid predators, than in plots not treated with the organophosphate insecticide. Aphid resistance to insecticides commonly used in potato crops is being assessed in laboratory assays. This information, along with graphs showing current flights of aphids that colonise potatoes and transmit potato viruses, and recommendations on suppressing the incidence of viruses in potatoes, is being promulgated in http://www.aphidwatch.com/potato/index.htm.
\end{abstract}

\section{INTEGRATED PEST AND DISEASE MANAGEMENT (IPM) FOR OUTDOOR LETTUCE}

\author{
G.P. WALKER ${ }^{1}$, P.J. WORKMAN ${ }^{1}$, M.A.W. STUFKENS ${ }^{2}$, P.J. \\ WRIGHT $^{3}$, J.D. FLETCHER ${ }^{2}$, M.S. QURESHI ${ }^{1}$ and S.I. DAVIS ${ }^{4}$ \\ ${ }^{1}$ Crop \& Food Research, PB 92169, Auckland \\ ${ }^{2}$ Crop \& Food Research, PB 4704, Christchurch \\ ${ }^{3}$ Crop \& Food Research, Cronin Rd, RD 1, Pukekohe \\ ${ }^{4}$ LeaderBrand Produce Ltd, PO Box 648, Gisborne
}

Corresponding author: walkerg@crop.cri.nz

The lettuce industry has initiated a project to develop and implement an integrated pest and disease management (IPM) programme for the control of insect pests and plant diseases in outdoor lettuce. Main aims are to ensure crop protection practices are more environmentally sustainable and to control the new insect pest, lettuce aphid (LA) Nasonovia ribisnigri. The project team includes grower groups from the two major lettuce-producing regions, Pukekohe and Gisborne, and other key industry partners, working together with Crop \& Food Research. Vegfed, the agrichemical industry and other industry partners are supporting this MAF Sustainable Farming Fund project. Results to date highlight the failure of foliar insecticides to control LA, but indicate that the use of an experimental systemic insecticide drench at pre-planting may be effective. Natural enemies may also have a major impact on pest aphid populations, in particular the native brown lacewing, Micromus tasmaniae. An aphid parasitoid, Aphidius sp., and an entomopathogenic fungus, Erynia sp., have been recovered from LA. Thysanoplusia orichalcea, soybean looper, was the only looper pest identified from lettuce. In an early summer virus survey, $30-46 \%$ of lettuce plant specimens collected in Gisborne and Pukekohe had LBVV (lettuce big vein virus). 